\title{
Characteristics and Controlling Factors of the Drought Runoff Coefficient
}

\author{
Rei Itsukushima $\mathbb{B}$
}

check for

updates

Citation: Itsukushima, R. Characteristics and Controlling Factors of the Drought Runoff Coefficient. Water 2021, 13, 1259. https://doi.org/10.3390/w13091259

Academic Editor: Leonardo V. Noto

Received: 29 March 2021

Accepted: 26 April 2021

Published: 30 April 2021

Publisher's Note: MDPI stays neutral with regard to jurisdictional claims in published maps and institutional affiliations.

Copyright: (C) 2021 by the author. Licensee MDPI, Basel, Switzerland. This article is an open access article distributed under the terms and conditions of the Creative Commons Attribution (CC BY) license (https:// creativecommons.org/licenses/by/ $4.0 /)$.
Department of Transdisciplinary Science and Engineering, Tokyo Institute of Technology, 4259 G5-4 Nagatsuta-cho, Midori-ku, Yokohama 226-8502, Japan; itsukushima.r.aa@m.titech.ac.jp; Tel.: +81-45-924-5515

\begin{abstract}
Increasing water demand due to population growth, economic development, and changes in rainfall patterns due to climate change are likely to alter the duration and magnitude of droughts. Understanding the relationship between low-flow conditions and controlling factors relative to the magnitude of a drought is important for establishing sustainable water resource management based on changes in future drought risk. This study demonstrates the relationship between low-flow and controlling factors under different severities of drought. I calculated the drought runoff coefficient for six types of occurrence probability, using past observation data of annual total discharge and precipitation in the Japanese archipelago, where multiple climate zones exist. Furthermore, I investigated the pattern of change in the drought runoff coefficient in accordance with the probability of occurrence of drought, and relationships among the coefficient and geological, land use, and topographical factors. The drought runoff coefficient for multiple drought magnitudes exhibited three behaviors, corresponding to the pattern of precipitation. Results from a generalized linear model (GLM) revealed that the controlling factors differed depending on the magnitude of the drought. During high-frequency droughts, the drought runoff coefficient was influenced by geological and vegetation factors, whereas land use and topographical factors influenced the drought runoff coefficient during low-frequency droughts. These differences were caused by differences in runoff, which dominated stream discharge, depending on the magnitude of the drought. Therefore, for effective water resource management, estimation of the volume of drought runoff needs to consider the pattern of precipitation, geology, land use, and topography.
\end{abstract}

Keywords: drought; geology; land use; topography; occurrence probability; water resource management

\section{Introduction}

The causes of droughts and adaptations to natural disasters have been studied from the perspectives of hydrology, environmental science, geology, meteorology, and agronomy [1]. The causes of droughts have been investigated in various regions by focusing on rainfall patterns [2-4], temperature [5,6], wind [7], and humidity [8]. In addition to the impacts of natural factors, intensification of drought is expected to occur because of growing water demand associated with population growth, economic development [9-11], and changes in the hydrological cycle associated with anthropogenic impacts, such as land-use-change [12-14].

Droughts are generally categorized into four types [15]. First, drought resulting from a lack of precipitation is defined as a meteorological drought [1,16]. Second, a shortage of surface or subsurface water in relation to water utilization, as determined by established water resource management, is defined as hydrological drought $[17,18]$. Stream water discharge is often used as an indicator hydrological droughts and is used in management and analyses of such droughts [19]. Third, agricultural drought indicates declining soil moisture, regardless of surface water resources, causing crop failure [20,21]. Finally, socioeconomic drought occurs in cases of defectiveness and incompatibility of the water resource system in relation to water demand [22,23]. 
Prolonged droughts cause severe socio-economic losses [24,25]. Economic loss arising from droughts has been estimated at USD 6-8 billion per year in the United States [26,27], with the EU suffering loss of 100 billion over the past 30 years [28]. The human damage caused by drought is even more serious. Droughts in Ethiopia/Sudan (1984) and the Sahel region (1974) killed 450,000 and 325,000 people, respectively [29].

Changes in the hydrological cycle resulting from climate change are expected to increase extreme drought events [1]. Unlike flood disasters, the influence of climate change on drought remains poorly understood. However, predictions of an intensification of drought due to climate change and population growth in central Africa [25] and increasing drought duration and severity in the interior southwest of the United States [30] have been reported. Furthermore, forecasts of drought using soil moisture as an indicator have indicated increasingly frequent drought events in Europe, regardless of the emission scenario applied [31].

Stream-flow discharge is an important indicator of hydrological drought because in many regions, water resources are obtained from surface water. Previous studies of stream discharge have focused on water resources, ecosystems, river channel formation, and flood management. In particular, the effects of alterations to flow regime on ecosystems have been studied [32-34], and the natural flow regime has been elucidated [35-38]. Research on the factors that influence flow discharge has focused on rainfall amount or pattern [39,40], land use [41,42], and watershed geology [43]. For research on flow regimes, the factors influencing low flows that are strongly related to drought have been investigated by focusing on watershed area, watershed elevation, ratio of urban area or forest cover, and geology [44-48]. However, these studies mainly focused on mountainous watersheds or a single factor. In addition, the low flows prevalent in these studies were not evaluated probabilistically. Therefore, the relationship between the frequency of low flow and its controlling factors remains unknown.

Increasing water demand, due to population growth and economic development and/or changes in rainfall patterns due to climate change, alters the duration and magnitude of droughts. To establish sustainable water resource management based on changes in future drought risk, it is important to understand the relationship between low flow and its controlling factors, in relation to the magnitude of drought. Consequently, I formulated the hypothesis that the factors controlling low surface flow vary according to the severity of the drought. This study is a first attempt at revealing this relationship. The surface water volume of each drought-occurrence probability was calculated based on long-term observational data. The relationships among the drought water volume of each occurrence probability and the controlling factors were analyzed. Multiple controlling factors related to geology, land use, and topography were introduced. Since my results identified the controlling factor of drought for each occurrence probability, they may contribute to the development of effective water resource management strategies through prediction of drought water volumes or the impact of climate change on surface water runoff.

\section{Materials and Methods}

\subsection{Location of the Study Area}

In this study, 44 watersheds across the Japanese archipelago, where discharge observations have been conducted over 30 years, were used. Only stations where the impact of flow regime regulation is small due to a dam were used in this study. Thus, observation stations whose watershed included a sub-catchment in which a dam is located were excluded if the sub-catchment exceeded $10 \%$ of the total area of the watershed. (Figure 1). Information about the sub-catchment areas of dams was obtained from the Japan Dam Foundation [49]. Watershed areas ranged from 47 to $8208 \mathrm{~km}^{2}$.

\subsection{Calculation of the Hydrological Data}

The runoff coefficient (calculated by dividing the depth of runoff by the amount of rainfall) has a clear relationship with controlling factors, including topography, land use, 
and geology $[50,51]$. Therefore, various analyses were conducted in this study, using the runoff coefficient during drought conditions.

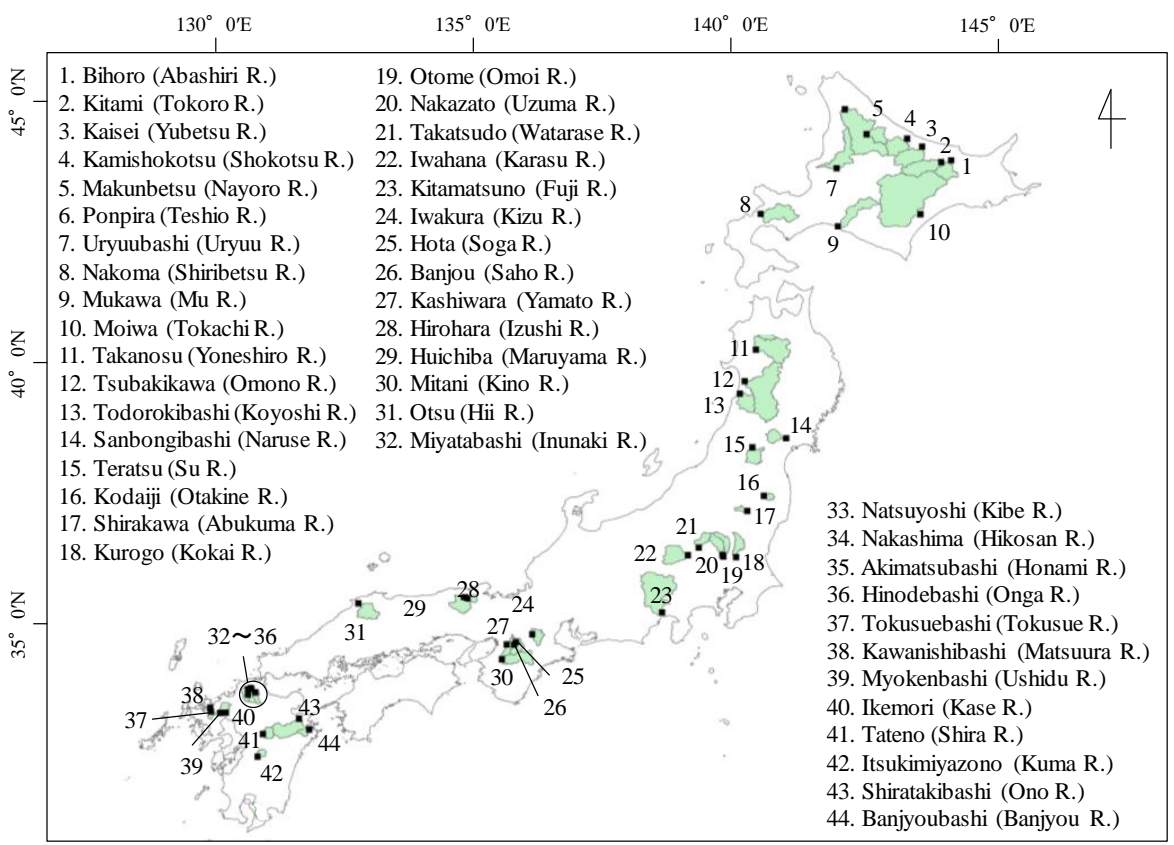

Figure 1. Location of the study site. In this study, I included watershed areas of 44 observation stations across the Japanese archipelago.

Although various time-scale indices have been used in the assessment of drought, propagation of a precipitation anomaly to streamflow was explained at the annual timescale [52,53], and annual discharge was frequently used as an evaluation indicator of drought [54-57]. Therefore, I used annual total discharge as an indicator to calculate the drought runoff coefficient. To investigate the relationship between the various frequencies of droughts (from low to high) and the controlling factors, the drought runoff coefficients for six different probability years of occurrence $(1 / 2,1 / 10,1 / 30,1 / 50,1 / 100$, and $1 / 400)$ were calculated. Further, I defined the runoff coefficient for six different probability of years of occurrence as the drought runoff coefficient.

The drought runoff coefficient of each occurrence probability for the 44 watersheds was calculated using the following equation:

$$
\mathrm{Qn} /(\mathrm{Pn} * \mathrm{~A})(1)
$$

where Qn is the estimated total discharge of each occurrence probability, $P n$ is the estimated precipitation amount of each occurrence probability, $\mathrm{n}=2,10,30,50,100$, and 400; and $A$ is the watershed area. The annual total discharge of each watershed was obtained from the Water Information System (http:/ / www1.river.go.jp / access on 10 April 2019). Annual precipitation data were obtained from the database of the Japan Meteorological Agency (http:/ / www.jma.go.jp/jma/index.html access on 10 April 2019). Data from observation stations with an observation period exceeding 30 years were used based on the research results, which indicates that the stability of reproduction statistics increases if the samples exceed approximately 30 [58]. A sample of the average depth of rainfall over the watershed area was calculated using a Voronoi diagram to objectively consider the effect of area on the amount of rainfall at the watersheds.

A sample of annual total discharge and the average depth of rainfall over the watershed of each observation point were calculated to estimate the total discharge and annual precipitation for occurrence probabilities of 2, 10,30, 50, 100, and 400 years. The hydrological statistics utility (ver. 1.5.) was used for the statistical analysis. I calculated the estimated design magnitude using 13 probability distributions, including the exponential distribution 
(EXP), Gumbel distribution (Gumbel), exponential-type distribution of maximum (SqrtEt), generalized extreme value distribution (Gev), log-Pearson type III distribution (real coordinate space) (LP3Rs), log-Pearson type III distribution (log coordinate space) (LogP3), Iwai method (Iwai), Ishihara Takase method (IshiTaka), the logarithmic normal distribution with three parameters (quantile method) (LN3Q), the logarithmic normal distribution with three parameters (Slade II) (LN3PM), the logarithmic normal distribution with two parameters (Slade I, L-moments method) (LN2LM), the logarithmic normal distribution with two parameters (Slade I, moments method) (LN2PM), and the logarithmic normal distribution with four parameters (Slade IV, moments method) (LN4PM) [59-68]. Among the 13 probability distributions, the estimated design magnitude was selected based on the standard least-squares criteria [69].

Numerous definitions of hydrological droughts have been proposed [15,70]. In this study, with reference to Whipple [71] and Changnon [72], low flow discharge was defined as being less than the average annual total discharge, and drought was defined as being less than $75 \%$ of the average annual total discharge. Furthermore, a discharge of $50 \%-75 \%$ of the average annual total discharge was defined as high-frequency drought, and a discharge of less than $50 \%$ was defined as low-frequency drought.

\subsection{Collecting Data for Controlling Factors}

Twelve indicators were assessed and classified into three categories (geological, landuse, and topographic factors) as controlling factors of the drought runoff coefficient.

As a geological factor, I focused on surface geology. Surface geology was classified into four groups (volcanic rock, plutonic rock, metamorphic rock, and sedimentary rock), based on geological creation processes, using a subsurface geological map at a scale of 1:200,000 (http:/ / nrb-www.mlit.go.jp/kokjo/inspect/landclassification/download/ access on 12 April 2019). The ratio of each surface geology was calculated using a geographic information system (GIS). In addition, metamorphic rock was excluded from the analysis because the composition ratio was less than $5 \%$ for all target watersheds.

Land-use data were obtained from the National Survey on the Natural Environment, conducted by the Japan Ministry of Environment (http: / /www.vegetation.biodic.go.jp/ legend.html access on 12 April 2019). Five classes of land use were recognized in this study (coniferous forest, broadleaf forest, mixed coniferous-broadleaf forest, cropland, and urban areas), and each class was considered to have different effects on runoff. The proportion of land use for each of the 44 watersheds was calculated using GIS.

I calculated the inverse of the channel slope and topographical gradient, form ratio, and roundness, as topographic factors. Channel slope was defined as the difference in elevation between the observation station and headwater divided by the length of the stream channel. Topographic gradient was obtained by averaging the slope angles calculated using the average maximum method in the watershed [73]. The form ratio was calculated by dividing the watershed area by the square of the length of the stream channel [74]. The form ratio approaches 1.0 if the shape of the basin is almost square or circular. Roundness was calculated by dividing the circumference of the watershed area by the watershed boundary length [75]. Topography data were obtained from the Global 3D Map Service (ALOS World 3D-30 m).

\subsection{Statistical Analyses}

To investigate the characteristics of the drought runoff coefficient and its relationship with the controlling factors, an analysis using nonmetric multidimensional scaling (NMDS) [76] was conducted. NMDS refers to a family of related ordination techniques, all of which use rank order information in a (dis) similarity matrix [77-79]. Similarity in the drought runoff coefficient between watersheds was calculated using the Bray-Curtis similarity [80]. From the permutation test $(n=999)$, controlling factors closely related to the classification of the drought runoff coefficient $(p<0.01)$ were presented as vectors. Of the indicators used as controlling factors, topographical gradient was excluded from 
the analysis because of the strong positive correlation $(r>0.07)$ between it and cropland. In addition, to investigate the difference in controlling factors among groups classified by similarity of the drought runoff coefficient, the controlling factors of each group were analyzed using one-way analysis of variance and the Kruskal-Wallis test. Further, Tukey's honestly significant difference (Tukey's HSD) and the Steel-Dwass test were conducted to reveal differences between groups if a significant difference was confirmed among groups.

A generalized linear model (GLM) was subsequently developed to formulate a predictive model for the drought runoff coefficient for each occurrence probability. Ten controlling factors were used as explanatory variables, similar to the NMDS. The GLM is an extinction model of a linear model that allows the incorporation of non-normal distributions of the response variables and linear transformations of the dependent variables [81]. I compared the obtained Akaike information criteria (AIC) [82] for each model using the stepwise selection method [83]. Finally, the lowest AIC model was adopted as the best model for each species. GLM was conducted using MASS (version 7.3-50).

\section{Results}

\subsection{Annual Precipitation and Drought Water Volume for Each Occurrence Probability}

The results for annual precipitation, volume of drought runoff, and drought water volume per unit drainage area for each occurrence probability are presented in Tables 1 and 2. The depth of precipitation and drought water volume per unit drainage area tended to be high in southwest Japan and low in north Japan. In addition, the differences in depth of precipitation and drought water volume per unit drainage area between observation stations decreased with an increasing probability of occurrence. Eight types of probability distributions were selected to calculate the drought water volume. The probability distributions indicated the highest adaptability for Gev, which was selected at 23 stations. LN3Q had the second highest adaptability and was selected at seven stations. In the calculation of precipitation depth, 10 types of probability distributions were selected. Adaptability followed the order: Gev (16 stations) > Gumbel (7 stations) > LN3Q (6 stations). From the calculation of the total discharge of each probability of occurrence, the percentages of the average annual discharge were $96 \%, 67 \%, 56 \%, 53 \%, 48 \%$, and $42 \%$ for probability of occurrences of 2, 10, 30, 50, 100, and 400 years, respectively. Therefore, the total discharge of the occurrence probability of 2 years corresponded to low-flow; 10, 30, and 50 years corresponded to the high-frequency drought; and 100 and 400 years corresponded to the low-frequency drought.

Table 1. The calculation result of precipitation amount for each occurrence probability.

\begin{tabular}{|c|c|c|c|c|c|c|c|c|c|c|}
\hline \multirow[t]{2}{*}{ No } & \multirow{2}{*}{$\begin{array}{l}\text { Observation } \\
\text { Station }\end{array}$} & \multirow{2}{*}{$\begin{array}{l}\text { Basin Area } \\
\left(\mathbf{k m}^{2}\right)\end{array}$} & \multicolumn{6}{|c|}{$\begin{array}{c}\text { Precipitation Amount for } \\
\text { Each Occurrence Probability (mm) }\end{array}$} & \multirow[t]{2}{*}{$\mathbf{N}$} & \multirow[t]{2}{*}{ Model } \\
\hline & & & $1 / 2$ & $1 / 10$ & $1 / 30$ & $1 / 50$ & $1 / 100$ & $1 / 400$ & & \\
\hline 1 & Bihoro & 824 & 925 & 731 & 659 & 633 & 602 & 554 & 31 & Gev \\
\hline 2 & Kitami & 1394 & 794 & 601 & 515 & 481 & 439 & 370 & 31 & Gev \\
\hline 3 & Kaisei & 1335 & 832 & 646 & 569 & 539 & 504 & 445 & 31 & Gev \\
\hline 4 & Kamishokotsu & 1051 & 929 & 701 & 595 & 552 & 500 & 411 & 31 & Gev \\
\hline 5 & Makunbetsu & 695 & 961 & 781 & 702 & 672 & 634 & 570 & 31 & Gumbel \\
\hline 6 & Ponpira & 4029 & 1161 & 964 & 864 & 822 & 769 & 673 & 31 & Gev \\
\hline 7 & Uryuubashi & 1661 & 1439 & 1199 & 1085 & 1038 & 980 & 880 & 31 & Gev \\
\hline 8 & Nakoma & 1402 & 1245 & 1035 & 936 & 897 & 847 & 762 & 31 & LN3Q \\
\hline 9 & Mukawa & 1228 & 1192 & 907 & 767 & 711 & 641 & 520 & 31 & Gev \\
\hline 10 & Moiwa & 8208 & 1041 & 813 & 709 & 668 & 617 & 532 & 31 & LN3Q \\
\hline 11 & Takanosu & 2109 & 1595 & 1285 & 1164 & 1120 & 1067 & 982 & 31 & Gev \\
\hline 12 & Tsubakikawa & 4305 & 1957 & 1642 & 1522 & 1477 & 1422 & 1332 & 31 & LN2LM \\
\hline 13 & Todorokibashi & 937 & 2155 & 1815 & 1684 & 1634 & 1575 & 1477 & 31 & LN2LM \\
\hline 14 & Sanbongibashi & 551 & 1387 & 1147 & 1054 & 1018 & 977 & 906 & 31 & Iwai \\
\hline 15 & Teratsu & 661 & 1195 & 972 & 890 & 861 & 826 & 772 & 31 & Gev \\
\hline 16 & Kodaiji & 180 & 1199 & 913 & 793 & 747 & 691 & 598 & 31 & Gev \\
\hline 17 & Shirakawa & 172 & 1957 & 1447 & 1200 & 1101 & 978 & 772 & 31 & Gev \\
\hline 18 & Kurogo & 580 & 977 & 774 & 685 & 651 & 608 & 536 & 31 & LN3Q \\
\hline 19 & Otome & 760 & 1381 & 1117 & 988 & 935 & 870 & 756 & 31 & Gev \\
\hline 20 & Nakazato & 205 & 1629 & 1285 & 1103 & 1026 & 929 & 755 & 31 & Gev \\
\hline 21 & Takatsudo & 472 & 1684 & 1323 & 1149 & 1080 & 994 & 847 & 31 & LN3Q \\
\hline 22 & Iwahana & 1228 & 1282 & 970 & 845 & 799 & 743 & 653 & 31 & Gumbel \\
\hline
\end{tabular}


Table 1. Cont.

\begin{tabular}{|c|c|c|c|c|c|c|c|c|c|c|}
\hline \multirow[t]{2}{*}{ No } & \multirow{2}{*}{$\begin{array}{l}\text { Observation } \\
\text { Station }\end{array}$} & \multirow{2}{*}{$\begin{array}{l}\text { Basin Area } \\
\left(\mathbf{k m}^{2}\right)\end{array}$} & \multicolumn{6}{|c|}{$\begin{array}{c}\text { Precipitation Amount for } \\
\text { Each Occurrence Probability }(\mathrm{mm})\end{array}$} & \multirow[t]{2}{*}{$\mathbf{N}$} & \multirow[t]{2}{*}{ Model } \\
\hline & & & $1 / 2$ & $1 / 10$ & $1 / 30$ & $1 / 50$ & $1 / 100$ & $1 / 400$ & & \\
\hline 23 & Kitamatsuno & 3540 & 1488 & 1107 & 973 & 923 & 865 & 772 & 31 & Iwai \\
\hline 24 & Iwakura & 501 & 1634 & 1266 & 1117 & 1060 & 992 & 877 & 31 & Iwai \\
\hline 25 & Hota & 163 & 1337 & 907 & 717 & 646 & 564 & 434 & 31 & LN3Q \\
\hline 26 & Banjou & 105 & 1372 & 1037 & 862 & 790 & 700 & 544 & 31 & Gev \\
\hline 27 & Kashiwara & 962 & 1397 & 1035 & 866 & 800 & 720 & 589 & 31 & LN3Q \\
\hline 28 & Hirohara & 195 & 1869 & 1616 & 1520 & 1484 & 1443 & 1381 & 31 & Gev \\
\hline 29 & Huichiba & 837 & 1721 & 1412 & 1287 & 1239 & 1181 & 1082 & 31 & LogP3 \\
\hline 30 & Mitani & 1049 & 1818 & 1435 & 1307 & 1261 & 1208 & 1122 & 31 & LP3Rs \\
\hline 31 & Otsu & 911 & 1866 & 1536 & 1401 & 1348 & 1282 & 1172 & 31 & LogP3 \\
\hline 32 & Miyatabashi & 123 & 1475 & 1112 & 950 & 886 & 808 & 677 & 31 & Gev \\
\hline 33 & Natsuyoshi & 47 & 1890 & 1404 & 1178 & 1087 & 977 & 791 & 31 & Gev \\
\hline 34 & Nakashima & 326 & 2262 & 1664 & 1379 & 1264 & 1125 & 891 & 31 & Gev \\
\hline 35 & Akimatsubashi & 113 & 1835 & 1368 & 1144 & 1055 & 944 & 756 & 31 & Gev \\
\hline 36 & Hinodebashi & 695 & 1751 & 1309 & 1101 & 1018 & 917 & 745 & 31 & Gev \\
\hline 37 & Tokusuebashi & 71 & 2252 & 1531 & 1256 & 1159 & 1049 & 883 & 31 & Exp \\
\hline 38 & Kawanishibashi & 120 & 2252 & 1618 & 1323 & 1205 & 1063 & 824 & 31 & Gev \\
\hline 39 & Myokenbashi & 95 & 1825 & 1342 & 1115 & 1024 & 912 & 725 & 31 & Gev \\
\hline 40 & Ikemori & 231 & 1748 & 1271 & 1037 & 943 & 826 & 632 & 31 & Gev \\
\hline 41 & Tateno & 386 & 2688 & 1992 & 1727 & 1629 & 1511 & 1316 & 31 & LogP3 \\
\hline 42 & Itsukimiyazono & 227 & 2217 & 1639 & 1414 & 1330 & 1232 & 1068 & 31 & LN3Q \\
\hline 43 & Shiratakibashi & 1381 & 1942 & 1441 & 1247 & 1174 & 1087 & 943 & 31 & $\log P 3$ \\
\hline 44 & Banjyoubashi & 278 & 2165 & 1548 & 1321 & 1238 & 1142 & 989 & 31 & Gumbel \\
\hline
\end{tabular}

Table 2. The calculation result of drought runoff volume, and drought water volume per unit drainage area for each occurrence probability.

\begin{tabular}{|c|c|c|c|c|c|c|c|c|c|c|c|c|c|c|}
\hline \multirow[t]{2}{*}{ No } & \multicolumn{6}{|c|}{$\begin{array}{l}\text { Drought Water Volume for } \\
\text { Each Occurrence Probability }\left(1^{6} \mathrm{M}^{3}\right)\end{array}$} & \multirow[t]{2}{*}{$\mathbf{N}$} & \multirow{2}{*}{ Model } & \multicolumn{6}{|c|}{$\begin{array}{l}\text { Drought Water Volume Per Unit Drainage } \\
\text { Area for Each Occurrence Probability }\end{array}$} \\
\hline & $1 / 2$ & $1 / 10$ & $1 / 30$ & $1 / 50$ & $1 / 100$ & $1 / 400$ & & & $1 / 2$ & $1 / 10$ & $1 / 30$ & $1 / 50$ & $1 / 100$ & $1 / 400$ \\
\hline 1 & 435 & 299 & 254 & 240 & 222 & 196 & 60 & Gev & 0.53 & 0.36 & 0.31 & 0.29 & 0.27 & 0.24 \\
\hline 2 & 699 & 521 & 461 & 441 & 415 & 373 & 60 & LN3PM & 0.50 & 0.37 & 0.33 & 0.32 & 0.30 & 0.27 \\
\hline 3 & 962 & 709 & 637 & 613 & 585 & 541 & 52 & LogP3 & 0.72 & 0.53 & 0.48 & 0.46 & 0.44 & 0.40 \\
\hline 4 & 909 & 680 & 610 & 588 & 565 & 532 & 60 & Gev & 0.86 & 0.65 & 0.58 & 0.56 & 0.54 & 0.51 \\
\hline 5 & 833 & 588 & 500 & 476 & 435 & 385 & 49 & LN3Q & 1.20 & 0.85 & 0.72 & 0.69 & 0.63 & 0.55 \\
\hline 6 & 5882 & 4762 & 4348 & 4167 & 4000 & 3704 & 46 & Gev & 1.46 & 1.18 & 1.08 & 1.03 & 0.99 & 0.92 \\
\hline 7 & 2326 & 1852 & 1667 & 1587 & 1515 & 1370 & 40 & LN3Q & 1.40 & 1.11 & 1.00 & 0.96 & 0.91 & 0.82 \\
\hline 8 & 2082 & 1724 & 1613 & 1563 & 1515 & 1449 & 52 & Gev & 1.49 & 1.23 & 1.15 & 1.11 & 1.08 & 1.03 \\
\hline 9 & 1250 & 833 & 667 & 625 & 556 & 438 & 42 & LogP3 & 1.02 & 0.68 & 0.54 & 0.51 & 0.45 & 0.35 \\
\hline 10 & 7143 & 5263 & 4545 & 4348 & 4000 & 3448 & 47 & LogP3 & 0.87 & 0.64 & 0.55 & 0.53 & 0.49 & 0.42 \\
\hline 11 & 3226 & 2632 & 2381 & 2283 & 2174 & 2000 & 55 & Iwai & 1.53 & 1.25 & 1.13 & 1.08 & 1.03 & 0.95 \\
\hline 12 & 8333 & 6667 & 5882 & 5882 & 5556 & 5263 & 71 & Gev & 2.07 & 1.65 & 1.46 & 1.46 & 1.38 & 1.30 \\
\hline 13 & 1961 & 1538 & 1389 & 1333 & 1266 & 1149 & 43 & LN3PM & 2.09 & 1.64 & 1.48 & 1.42 & 1.35 & 1.23 \\
\hline 14 & 877 & 676 & 610 & 585 & 559 & 513 & 41 & Iwai & 1.59 & 1.23 & 1.11 & 1.06 & 1.01 & 0.93 \\
\hline 15 & 833 & 625 & 526 & 500 & 476 & 400 & 42 & Gumbel & 1.26 & 0.95 & 0.80 & 0.76 & 0.72 & 0.61 \\
\hline 16 & 137 & 95 & 83 & 78 & 72 & 65 & 36 & Gev & 0.76 & 0.53 & 0.46 & 0.43 & 0.40 & 0.36 \\
\hline 17 & 196 & 137 & 116 & 110 & 101 & 88 & 48 & Gev & 1.14 & 0.80 & 0.68 & 0.64 & 0.59 & 0.51 \\
\hline 18 & 714 & 526 & 455 & 435 & 400 & 357 & 55 & Gumbel & 1.23 & 0.91 & 0.78 & 0.75 & 0.69 & 0.62 \\
\hline 19 & 1064 & 690 & 524 & 461 & 388 & 274 & 36 & Gev & 1.40 & 0.91 & 0.69 & 0.61 & 0.51 & 0.36 \\
\hline 20 & 217 & 141 & 110 & 98 & 84 & 62 & 37 & Gev & 1.06 & 0.69 & 0.53 & 0.48 & 0.41 & 0.30 \\
\hline 21 & 588 & 370 & 286 & 263 & 227 & 182 & 51 & LN3Q & 1.25 & 0.78 & 0.61 & 0.56 & 0.48 & 0.39 \\
\hline 22 & 901 & 592 & 478 & 439 & 392 & 318 & 42 & Gev & 0.73 & 0.48 & 0.39 & 0.36 & 0.32 & 0.26 \\
\hline 23 & 2174 & 1163 & 885 & 794 & 699 & 552 & 49 & LN3Q & 0.61 & 0.33 & 0.25 & 0.22 & 0.20 & 0.16 \\
\hline 24 & 500 & 314 & 240 & 214 & 182 & 133 & 42 & Gev & 1.00 & 0.63 & 0.48 & 0.43 & 0.36 & 0.27 \\
\hline 25 & 200 & 118 & 94 & 86 & 78 & 65 & 24 & Gumbel & 1.23 & 0.72 & 0.58 & 0.53 & 0.48 & 0.40 \\
\hline 26 & 102 & 64 & 52 & 48 & 43 & 36 & 29 & Gumbel & 0.97 & 0.61 & 0.49 & 0.46 & 0.41 & 0.35 \\
\hline 27 & 840 & 552 & 446 & 410 & 369 & 308 & 29 & Exp & 0.87 & 0.57 & 0.46 & 0.43 & 0.38 & 0.32 \\
\hline 28 & 278 & 213 & 189 & 180 & 169 & 154 & 35 & Iwai & 1.42 & 1.09 & 0.97 & 0.93 & 0.87 & 0.79 \\
\hline 29 & 1205 & 943 & 855 & 820 & 781 & 719 & 32 & LP3Rs & 1.44 & 1.13 & 1.02 & 0.98 & 0.93 & 0.86 \\
\hline 30 & 1282 & 862 & 704 & 649 & 581 & 474 & 28 & Gev & 1.22 & 0.82 & 0.67 & 0.62 & 0.55 & 0.45 \\
\hline 31 & 1389 & 1064 & 935 & 885 & 826 & 730 & 23 & Gumbel & 1.52 & 1.17 & 1.03 & 0.97 & 0.91 & 0.80 \\
\hline 32 & 141 & 93 & 79 & 74 & 68 & 60 & 58 & $\operatorname{LogP3}$ & 1.15 & 0.76 & 0.64 & 0.60 & 0.56 & 0.49 \\
\hline 33 & 76 & 46 & 35 & 31 & 26 & 19 & 30 & Gev & 1.61 & 0.98 & 0.74 & 0.65 & 0.55 & 0.39 \\
\hline 34 & 412 & 260 & 207 & 188 & 167 & 134 & 62 & SqrtEt & 1.26 & 0.80 & 0.64 & 0.58 & 0.51 & 0.41 \\
\hline 35 & 156 & 102 & 84 & 78 & 71 & 60 & 38 & Gumbel & 1.38 & 0.90 & 0.74 & 0.69 & 0.63 & 0.53 \\
\hline 36 & 952 & 595 & 469 & 426 & 376 & 300 & 55 & SqrtEt & 1.37 & 0.86 & 0.68 & 0.61 & 0.54 & 0.43 \\
\hline 37 & 96 & 58 & 45 & 41 & 36 & 28 & 41 & SqrtEt & 1.35 & 0.82 & 0.64 & 0.57 & 0.50 & 0.40 \\
\hline 38 & 185 & 106 & 81 & 71 & 61 & 46 & 38 & Gev & 1.54 & 0.89 & 0.67 & 0.60 & 0.51 & 0.38 \\
\hline 39 & 133 & 78 & 56 & 48 & 38 & 25 & 27 & Gev & 1.40 & 0.82 & 0.59 & 0.50 & 0.40 & 0.26 \\
\hline 40 & 222 & 133 & 109 & 101 & 93 & 80 & 25 & Gev & 0.96 & 0.58 & 0.47 & 0.44 & 0.40 & 0.35 \\
\hline 41 & 714 & 500 & 435 & 400 & 370 & 323 & 24 & Gumbel & 1.85 & 1.30 & 1.13 & 1.04 & 0.96 & 0.84 \\
\hline 42 & 526 & 345 & 278 & 256 & 233 & 192 & 35 & LN3Q & 2.32 & 1.52 & 1.22 & 1.13 & 1.02 & 0.85 \\
\hline 43 & 1818 & 1282 & 1124 & 1064 & 1000 & 893 & 66 & LN3PM & 1.32 & 0.93 & 0.81 & 0.77 & 0.72 & 0.65 \\
\hline 44 & 357 & 209 & 165 & 150 & 133 & 108 & 57 & LN3Q & 1.28 & 0.75 & 0.59 & 0.54 & 0.48 & 0.39 \\
\hline
\end{tabular}




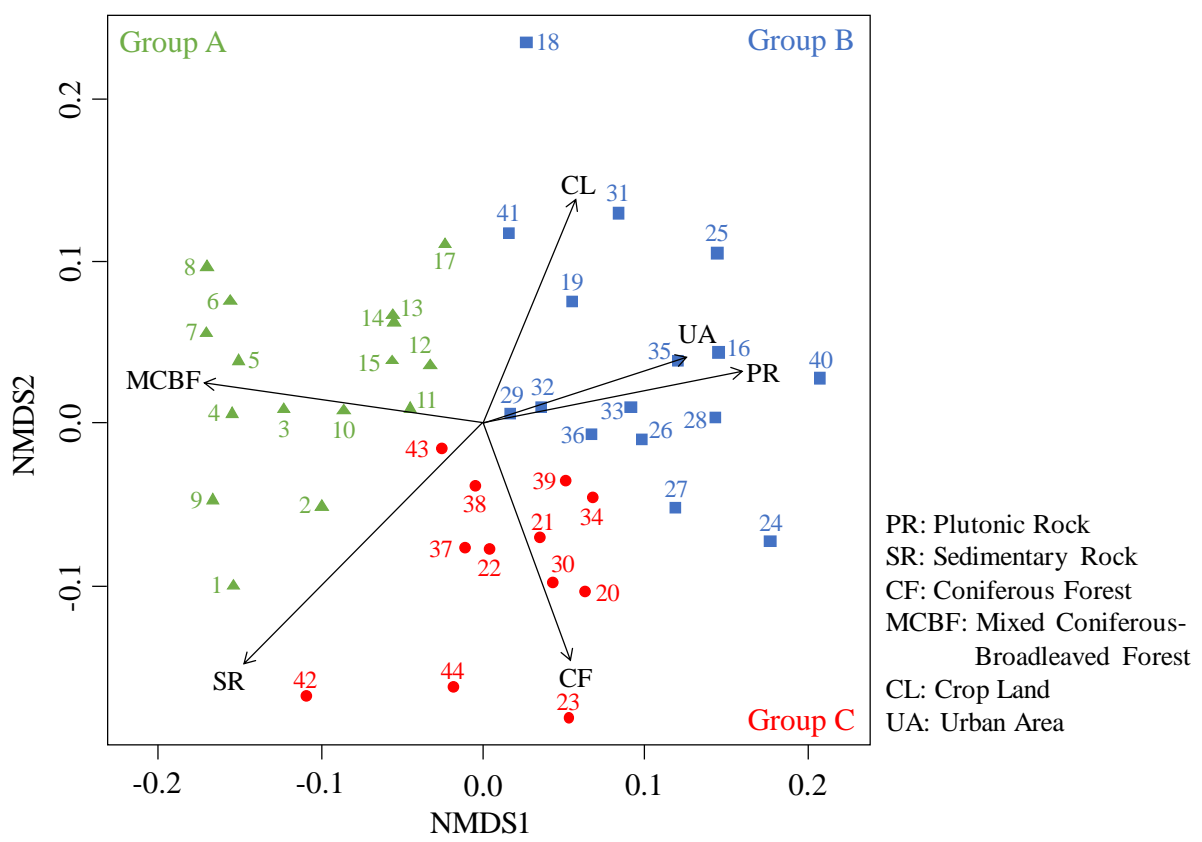

Figure 2. Result of NMDS using drought runoff coefficient of each occurrence probability. NMDS, nonmetric multidimensional scaling.

Group A ( $\mathrm{N}=16)$ was located in the second and third quadrats and was composed of watersheds dominated by a mixed coniferous and broadleaf forest. The watersheds belonging to Group A were also characterized by low ratios of urban area and plutonic rocks. Group B $(\mathrm{N}=16)$ was located in the first and fourth quadrats, composed of watersheds dominated by urban areas or croplands. The surface geology of the watersheds belonging to Group B was dominated by plutonic rocks. Group C $(\mathrm{N}=12)$ was located in the third and fourth quadrats, and was composed of watersheds characterized by a high proportion of coniferous forest.

The average runoff coefficient was largest in group $A$ and smallest in group $C$ in all occurrence probabilities. In addition, the difference in the drought runoff coefficient between occurrence probabilities was smaller in Group A than in the other groups, exhibiting a slight difference between the occurrence probabilities of 2 and 400 years. However, in Group $C$, the drought runoff coefficient tended to decrease with increasing occurrence probability. In Group B, the change in drought runoff coefficient with occurrence probability indicated an intermediate behavior between Groups A and C. Although the drought runoff coefficient decreased to an occurrence probability of 30 years, it had an almost constant value at occurrence probabilities exceeding 30 years (Figure 3). A significant difference between groups $A$ and $C$ was confirmed in all occurrence probabilities $(p<0.01)$. In addition, a significant difference between groups $\mathrm{A}$ and $\mathrm{B}$ was confirmed in the occurrence probabilities of $10,30,50,100$, and 400 years $(p<0.01)$.

\subsection{Characteristics of Controlling Factors in Each Group}

Figure 4 presents a boxplot of the controlling factors for each group. The geological factors VR and SR yielded similar results. The highest values for both indicators were observed in group $\mathrm{A}$, followed by those in groups $\mathrm{C}$ and $\mathrm{B}$. One-way analysis of variance indicated a significant difference among the three groups $(p<0.01)$. Tukey's HSD test revealed a significant difference between Group B and the other two groups $(p<0.01)$ for both factors. However, the PR exhibited the opposite trend. The average value for PR was highest in group B (41\%), followed by those in groups C (7.2\%) and A (2.7\%). The Kruskal-Wallis test revealed significant differences among the groups $(p<0.01)$. In addition, the Steel-Dwass test revealed that the PR of group B was significantly higher than that of groups A $(p<0.01)$ and $C(p<0.01)$. 


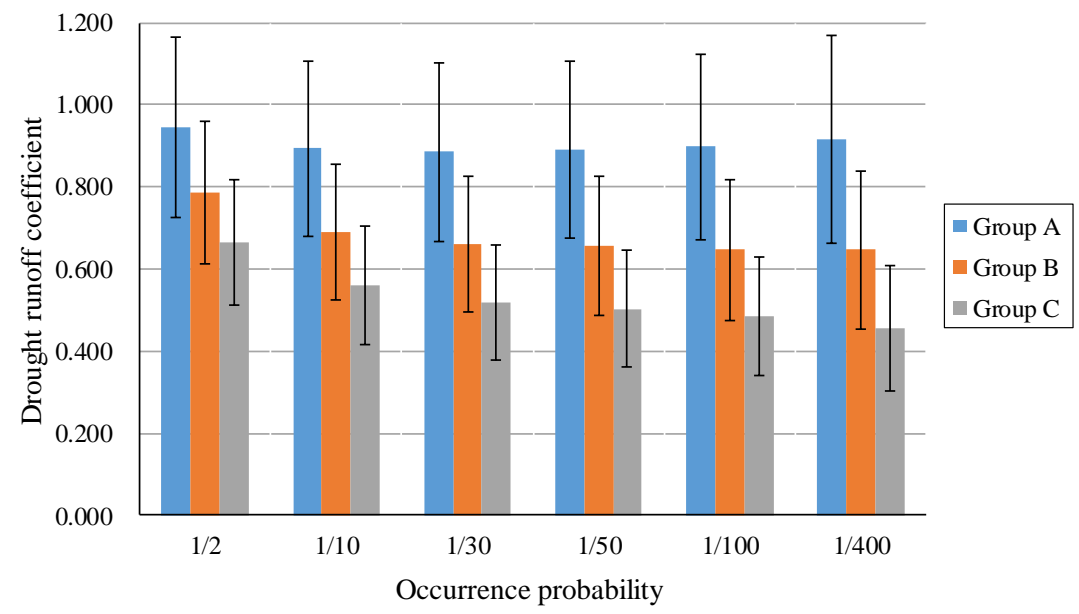

Figure 3. Characteristics of the average value of drought runoff coefficient for each occurrence probability in three groups.
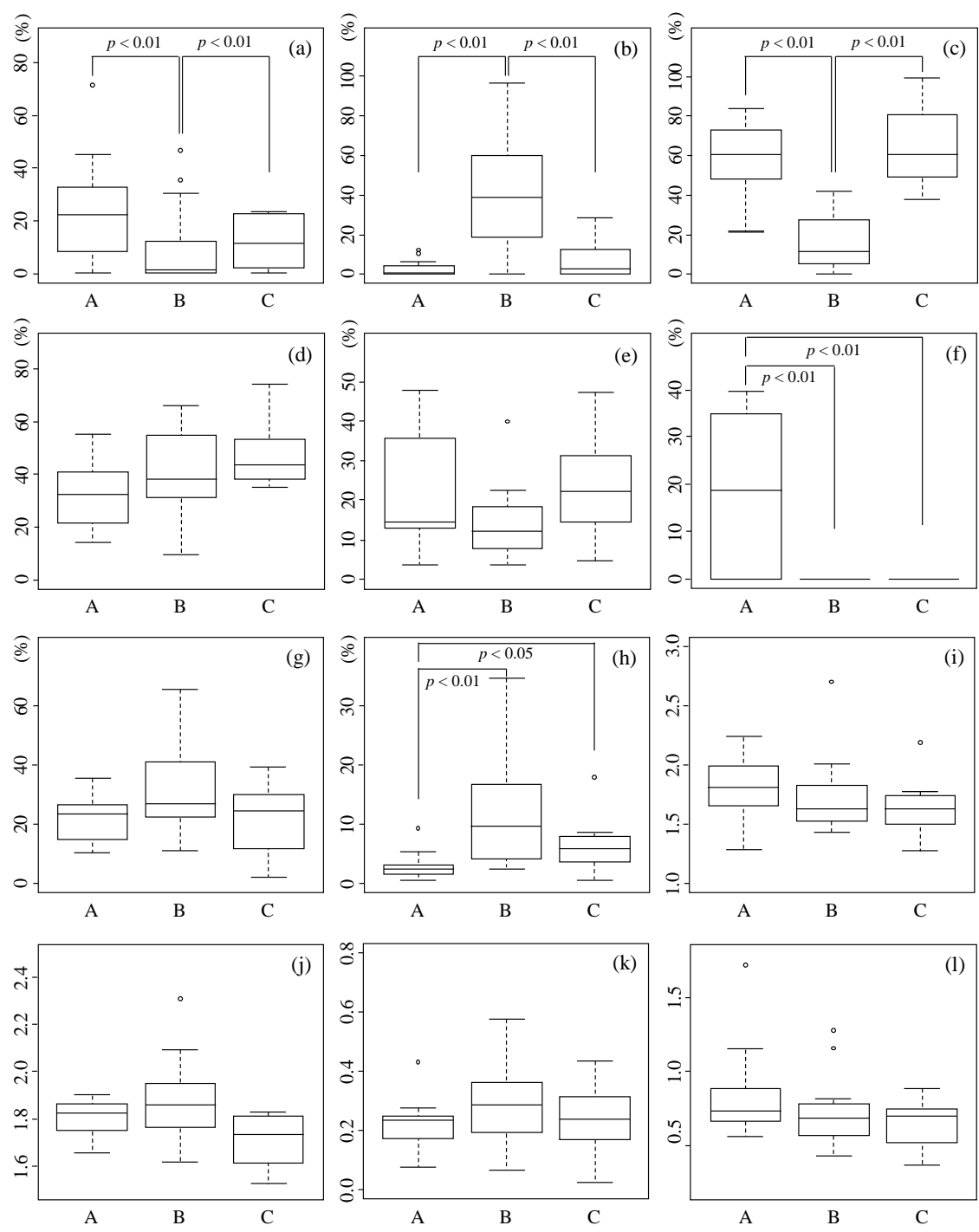

Figure 4. Comparison of controlling factors between groups: (a) VR: Volcanic Rock, (b)PR: Plutonic Rock, (c) SR: Sedimentary Rock, (d) CF: Coniferous Forest, (e)BF: Broadleaf Forest, (f) MCBF: Mixed Coniferous-Broadleaved Forest, (g) CL: Crop Land, (h) UA: Urban Area, (i) CS: Channel Slope (j) TGr Topographical Gradient (k) FR: Form Ratio, (1) Ro: Roundness. 
MCBF was the only land-use factor confirmed in watersheds belonging to Group A. The average value for UA was highest in group B (12\%), followed by groups C (6.4\%) and A $(2.9 \%)$. The Kruskal-Wallis test revealed significant differences among groups $(p<0.01)$. In addition, the Steel-Dwass test revealed that the UA of group A was significantly lower than that of groups B $(p<0.01)$ and $C(p<0.05)$.

By contrast, one-way analysis of variance and the Kruskal-Wallis test indicated no significant difference for land-use factors BF, CF, and CL, and all topographical factors.

\section{Discussion}

\subsection{Difference in Drought Runoff Coefficient between Areas}

Observation stations located on the Japanese archipelago were classified into three groups, A, B, and C, on the basis of their drought runoff coefficient. Furthermore, as a result of this classification, geographically close rivers tend to be classified into similar groups. The tendency of geographically adjacent rivers to show similar hydrological characteristics has been confirmed in previous studies [84]. Sawicz et al. [85] explained that this tendency was caused by climatic and landscape characteristics changing slowly in space. The drought runoff coefficient of Group A exhibited high values, regardless of changes in occurrence probability. However, the drought runoff coefficient of Group C decreased with increasing occurrence probability. Catchment classification using runoff characteristics is important from the standpoint of prediction in ungauged basins or the creation of a common language [86]. Carely et al. [87] analyzed the runoff coefficient of rivers in Sweden, Scotland, Canada, and the United States, and divided rivers into two groups (catchments that rapidly generate precipitation runoff and catchments that more readily store water and exhibit a more delayed release). In addition, Laaha and Blosch [48] demonstrated that seasonality of rainfall was the optimal parameter for the classification of watersheds using low-flow data. The change in the drought runoff coefficient with increasing probability of occurrence for Group B exhibited a trend intermediate between Groups A and C. In this study, I used the drought runoff coefficient as the indicator, which was calculated by dividing total river runoff by total rainfall in each area. The drought runoff coefficient was calculated annually and therefore, the difference in the trend of the drought runoff coefficient of occurrence probability among groups was thought to be partly caused by the seasonality of rainfall across different time-scales. However, it is clear that watershed factors exerted a strong influence on the drought runoff coefficient because the characteristics of the watershed indicator differed for each classification, based on the NMDS results. The stable and high drought runoff coefficient of Group A, which was composed of watersheds in regions experiencing heavy snow, can be attributed to its specific pattern of precipitation, compared to those of other areas. This is also due to low evapotranspiration in high-latitude areas [88,89]. Takahashi et al. [90] investigated the drought water volume of this water source area and concluded that the large drought water volume of north Japan results from the stable water supply induced by spring snowmelt, and associated runoff and intermittent rainfall in fall. This water supply contributes to the maintenance of groundwater during the drought season. In addition, the drought risk of the area influenced by spring snowmelt runoff will increase owing to the decreasing depth of precipitation in winter and spring as a result of climate change. This confirms the importance of snowmelt runoff in water resource recharge [91].

A trend of decreasing drought runoff coefficient with increasing occurrence probability was found in Group C, which is composed of watersheds within the southwest Japanese archipelago. In these watersheds, the depth of precipitation largely depends on the intense rainfall of a typhoon or rainy season [92]. Therefore, the low supply of water into the ground during drought results in a low drought runoff coefficient when the probability of occurrence is high. In addition to the influence of the pattern of precipitation, the geology of the watersheds belonging to Group C also influenced the low drought runoff coefficient. Group C was composed of watersheds with a high proportion of sedimentary rock (Figure 4). Furthermore, the geological age of the sedimentary rock of these watersheds 
(the Mesozoic and Paleozoic ages) is older than that in other areas [93]. The low drought runoff coefficient was thought to be caused by the high degree of agglomeration of the rock, which is a result of the high geological age influencing the deep percolation of precipitation. Group A is also an area with a large proportion of sedimentary rock, but it is thought that the difference in geological age and the influence of rainfall patterns was dominant, resulting in a difference in the rate of drought outflow from Group C.

\subsection{Controlling Factors and the Drought Runoff Coefficient}

\subsubsection{Occurrence Probability of Drought and Controlling Factors}

Hydrologic units reflect the characteristics of climate, geology, topography, and land use of watersheds $[86,94]$. Therefore, in this section, I describe the relationship between the watershed characteristics (geology, land use, and topography) and the drought runoff coefficient for each occurrence probability. The GLM investigated the relationships between the drought runoff coefficient and controlling factors, and demonstrated that geological factors and land-use factors (vegetation) influenced the drought runoff coefficient in highfrequency drought. In contrast, land-use factors and topographic factors were selected as influencing factors in low-frequency drought. Comparing the standard partial regression coefficient obtained from the GLM as a function of the occurrence probability, the value of MCBF of land-use factors was higher than that of geological factors in the high-frequency drought. In the drought with an occurrence probability of 30 years, the value of land-use factor exceeded that of the geological factor, and CF was selected as the most influential indicator. Furthermore, CS was selected as an important factor in low-frequency drought, in addition to CF. This is considered to be due to the fact that the runoff components that control flow discharge differ, depending on drought frequency. Geological factors and land-use factors were selected as the controlling factors in the total discharge of occurrence probability of 2 and 10 years. These factors are closely related to surface runoff or subsurface flow. In contrast, for the low-frequency drought, factors related to a longer time-scale hydrological cycle, such as ground-water level, were selected. Previous research investigating the relationship between flood discharge and controlling factors for multiple occurrence probabilities demonstrated that a coniferous forest increases discharge in lowfrequency floods, whereas topographical factors increase discharge in high-frequency floods [51]. In addition, the controlling factor for stream discharge changes from rainfall to geological factors with the threshold of ordinary water discharge [44]. From these results, it is clear that the controlling factors change according to the frequency of both flood and drought events.

\subsubsection{Geological Factors and the Drought Runoff Coefficient}

Some studies have demonstrated that geology is one of the factors controlling the flow regime [95-97]. The reasons for differences in drought runoff or base flow as a function of geology are that (i) the retention capacity of groundwater differs based on geology; and (ii) the infiltration capacity of soils differs as a function of geology $[98,99]$. From the GLM, PR and SR (among the geological factors) were selected as controlling factors that decreased the drought runoff coefficient in high-frequency drought (Table 3). This is incompatible with the results of Mushiake et al. [44], who noted that granite (classified as a plutonic rock) is a factor in increasing drought discharge. This contrast in results was caused by the location of the study area and the observation period of the data. Mushiake et al. [44] used the average drought value based on a relatively short-term period. In steep mountain rivers with a small watershed area, rainfall rapidly flows out, and the ratio of surface and intermediate runoff to drought discharge is thought to be larger. In addition, the influence of local deep percolation in bedrock cracks appears to be highly significant in small watersheds. Therefore, a minimum basin area is necessary to evaluate the effect of geological factors on the drought runoff coefficient. In contrast, Yokoo and Oki [100] demonstrated that geological age exerts an influence on drought runoff. In particular, based on an investigation of watersheds with an area exceeding $100 \mathrm{~km}^{2}$, quaternary geology was 
found to be an increasing factor for drought runoff. Rocks of different geological ages differ in the degree of consolidation and result in a difference in the degree of deep percolation. Furthermore, as diagenesis progresses, water exchange between an aquifer and a river is less likely to occur. Therefore, geological age is an important factor for characterizing the drought runoff coefficient. Therefore, it is necessary to consider both geological type and geological age as indicators for predicting drought runoff.

Table 3. Analysis of the relationship between drought runoff coefficient of each occurrence probability and controlling factors by GLM

\begin{tabular}{|c|c|c|c|c|c|c|}
\hline \multirow[t]{2}{*}{ Controlling Factors } & \multicolumn{6}{|c|}{ Occurrence Probability } \\
\hline & $1 / 2$ & $1 / 10$ & $1 / 30$ & $1 / 50$ & $1 / 100$ & $1 / 400$ \\
\hline \multicolumn{7}{|l|}{ Geological factor } \\
\hline VR & -0.065 & & & & & \\
\hline PR & $-0.135^{* *}$ & $-0.087 *$ & -0.072 & -0.076 & -0.068 & \\
\hline SR & $-0.158^{* *}$ & $-0.107^{* *}$ & -0.091 & -0.097 & -0.094 & \\
\hline \multicolumn{7}{|l|}{ Land use factor } \\
\hline $\mathrm{BF}$ & $0.098 *$ & $0.087^{* *}$ & & -0.047 & -0.047 & -0.059 \\
\hline $\mathrm{CF}$ & & & $-0.120 * *$ & $-0.159^{* * *}$ & $-0.155^{* *}$ & $-0.205^{* * *}$ \\
\hline MCBF & $0.122 * *$ & $0.117^{* *}$ & & & & \\
\hline CL & & & -0.078 & $-0.106^{*}$ & -0.103 & -0.083 \\
\hline UA & & & $-0.078^{*}$ & $-0.079 *$ & $-0.087^{*}$ & $-0.084 *$ \\
\hline \multicolumn{7}{|l|}{ Topographical factor } \\
\hline CS & 0.049 & $0.098^{* *}$ & $0.105^{* *}$ & $0.105^{* *}$ & $0.073 *$ & 0.118 * \\
\hline FR & & 0.047 & 0.047 & & & \\
\hline $\mathrm{RO}$ & & & & -0.052 & & -0.089 \\
\hline $\mathrm{R}^{2}$ & 0.377 & 0.441 & 0.435 & 0.444 & 0.421 & 0.430 \\
\hline AIC & -23.013 & -24.676 & -20.005 & -17.291 & -12.615 & -4.9517 \\
\hline
\end{tabular}

In addition to plutonic rock, sedimentary rock was selected as a factor causing a decline of the drought runoff coefficient for occurrence probabilities of 2 and 10 years. The infiltration capacity of sedimentary rocks appears to change with the degree of agglomeration. However, flysch (classified as a sedimentary rock), is a factor for increasing drought or flood [101]. The GLM results support the finding that the low permeability of sedimentary rock is a controlling factor in high-frequency drought.

While much research has revealed the relationship between geology and drought discharge, some researchers have claimed a stronger influence of topography than that of surface geology on groundwater level [102]. To clarify the more precise influence of geology, it is important to analyze the relationship between drought and geology under the same conditions of watershed area, topography, land use, and drought magnitude. In addition, the degree of agglomeration of the rock is closely related to runoff phenomena, as discussed above. Further research is needed to quantify the relationship between drought runoff discharge and geology in various regions.

\subsubsection{Land Use Factors and the Drought Runoff Coefficient}

Changes in the number of available water resources due to an alteration in the rainfallrunoff relationship caused by vegetation changes have long been recognized [103]. In addition, runoff volume differs between coniferous and broadleaf forests, owing to the dissimilarities in evapotranspiration (ET) [104-106]. My research results also indicate the different functions of coniferous and broadleaf forests. Based on the GLM, the broadleaf forest was selected as an increasing factor for the drought runoff coefficient for highfrequency drought, whereas coniferous forest was a decreasing factor for low-frequency drought (Table 3). This is thought to be due to differences in ET. Previous research has indicated that the change in runoff volume is larger for a coniferous forest when a coniferous 
forest and a broadleaf forest are cleared [107]. Furthermore, the drought runoff volume increases because of the clearing of the coniferous forest [103,108-110]. These results support the GLM results. Moreover, I presume that the reason for the coniferous forest decreasing the drought coefficient in low-frequency drought is as follows: Since ET and canopy interception occur constantly regardless of drought magnitude, the amount of precipitation available to generate surface runoff decreases as the depth of precipitation decreases, and the effects of coniferous forests become dominant. In contrast, ET and runoff volume are altered by the management status of the forest, the condition of the forest floor, and tree age [111-113]. This study examined the relationship between the runoff coefficient and vegetation type as land-use factors for relatively large watersheds. Therefore, the differences between broadleaf and coniferous forests have become clear. However, it should be noted that the runoff coefficient could change, even within the same forest type, if the targeted watershed is smaller.

Land use changes significantly alter the mechanism of runoff [114]. Among landuse changes, urbanization increases flood peak discharge [115] and decreases minimum flow [116]. The main cause of urbanization decreasing the minimum flow is a decrease in the infiltration area and a decline in the base flow due to the consolidation of pipe systems $[117,118]$. The GLM results indicate that urban areas are a decreasing factor for the drought runoff coefficient in low-frequency droughts. The composition of tree species in the forest is an important controlling factor for high-frequency drought because the source of surface water mainly depends on rainfall in the upstream area. Therefore, the impact of urbanization is assumed to be relatively low in high-frequency droughts. In contrast, surface water from the upstream area is decreased in low-frequency drought and therefore, the influence of urbanization, including the limitation of rainfall infiltration or supply of surface water from groundwater, is assumed to be dominant. In contrast to this study, Ralf and Bloschl [119] demonstrated that land use, soil type, and geology do not exert strong influences on the volume of runoff in the normal stage in 459 rivers in Austria. Based on the results of my analysis, the magnitude of the impact of land use on the runoff coefficient varied, depending on the scale of runoff.

\subsubsection{Topographic Factors and the Drought Runoff Coefficient}

To determine the relationship among topographic factors and drought runoff, the influence of river length, watershed gradient, average watershed width, and altitude on base flow were examined [100,120-123]. The GLM indicated that channel slope is an increasing factor for the drought runoff coefficient at occurrence probabilities of 10 years or more (Table 3). This result supports the research of Moliere et al. [120], who demonstrated that zero flow days increase in high-gradient rivers. However, topographic factors were not selected as controlling factors for the drought runoff coefficient at an occurrence probability of 2 years. Runoff discharge in high-frequency droughts is mainly governed by surface runoff. Therefore, the geological or land-use factors closely related to surface runoff were dominant, rather than topographical factors. However, the ratio of groundwater appeared to increase with increasing river discharge during low-frequency drought. Therefore, the topographic factor most closely related to groundwater was selected. Moreover, this study focused on observation stations in various basins, including both mountainous and alluvial areas. The interaction between groundwater and surface water is considered to be more active in alluvial channels; therefore, the drought runoff coefficient was higher in low-gradient watersheds.

\section{Conclusions}

This manuscript reports relationships among drought runoff and controlling factors (geological, land-use, and topographical factors) as a function of occurrence probability.

Classification results of the drought runoff coefficient across multiple drought magnitudes indicated three types of behavior for the drought runoff coefficient. The group with watersheds influenced by snowmelt runoff had a high drought runoff coefficient, regardless 
of drought magnitude. However, the drought runoff coefficient of the group influenced by rainfall intensity decreased with increasing drought magnitude. The drought runoff coefficient of the remaining group exhibited intermediate behavior between these two groups. In addition, this classification result indicated a significant relationship between the proportion of plutonic rock, sedimentary rock (geological factors), urban areas, and a mixed coniferous-broadleaved forest (land-use factors).

The GLM revealed that the controlling factors differed depending on the magnitude of drought. In high-frequency drought, the drought runoff coefficient was influenced by geological and vegetation factors, whereas land use and topographical factors influenced the drought runoff coefficient in low-frequency drought. These differences were caused by the differences in the runoff component, which dominated stream discharge in relation to drought magnitude.

This research clarified that a change in the drought runoff coefficient due to occurrence probability differs depending on the precipitation pattern or climatic zone, and the controlling factors of the drought runoff coefficient changed in accordance with the occurrence probability. Therefore, for effective water resource management, estimation of the drought runoff volume needs to consider precipitation pattern, geology, land use, and topography to correspond to the magnitude of the drought. Because the results clarify the controlling factors of drought runoff for each occurrence probability, this study contributes to effective water resource management by estimating the drought volume for climatic zones and by predicting changes in drought volume due to climate change. Further research is needed to investigate applicable climate zones and the influence of catchment scale on the relationship between drought and the controlling factors. Although not included in this study, dimensionless numbers describing the geomorphological characteristics of catchments, including stream order [124,125], bifurcation or ratio hillslope form [126], were revealed to explain the hydrogeomorphological characteristics of the catchment. Therefore, I can improve my model by using these factors.

Funding: This work was supported by JSPS KAKENHI (grant number JP19H02250).

Institutional Review Board Statement: Not applicable.

Informed Consent Statement: Not applicable.

Data Availability Statement: The data that support the findings of this study are available from the corresponding author, upon reasonable request.

Conflicts of Interest: The author declares no conflict of interest.

\section{References}

1. Mishra, A.K.; Singh, V.P. A review of drought concepts. J. Hydrol. 2010, 391, 202-216. [CrossRef]

2. Verschuren, D.; Lalrd, K.R.; Cumming, B.F. Rainfall and drought in equatorial east Africa during the past 1100 years. Nature 2000, 403, 410-414. [CrossRef]

3. Tabari, H.; Abghari, H.; Hosseinzadeh Talaee, P. Temporal trends and spatial characteristics of drought and rainfall in arid and semiarid regions of Iran. Hydrol. Process. 2012, 26, 3351-3361. [CrossRef]

4. Tfwala, C.M.; van Rensburg, L.D.; Schall, R.; Dlamini, P. Drought dynamics and interannual rainfall variability on the Ghaap plateau, South Africa, 1918-2014. Phys. Chem. Earth 2018, 107, 1-7. [CrossRef]

5. Nicholls, N. The changing nature of Australian droughts. Clim. Chang. 2004, 63, 323-336. [CrossRef]

6. Hein, A.; Condon, L.; Maxwell, R. Evaluating the relative importance of precipitation, temperature and land-cover change in the hydrologic response to extreme meteorological drought conditions over the North American High Plains. Hydrol. Earth Syst. Sci. 2019, 23, 1931-1950. [CrossRef]

7. Namias, J. Written in the winds: The great drought of '88. Weatherwise 1989, 42, 85-87. [CrossRef]

8. Behrangi, A.; Loikith, P.C.; Fetzer, E.J.; Nguyen, H.M.; Granger, S.L. Utilizing humidity and temperature data to advance monitoring and prediction of meteorological drought. Climate 2015, 3, 999-1017. [CrossRef]

9. Frederiksen, H.D. Water crisis in developing world: Misconceptions about solutions. J. Water Res. Plan. Manag. 1996, 122, 79-87. [CrossRef]

10. Xiao-jun, W.; Jian-yun, Z.; Shahid, S.; ElMahdi, A.; Rui-min, H.; Zhen-xin, B.; Ali, M. Water resources management strategy for adaptation to droughts in China. Mitig. Adapt. Strateg. Glob. Chang. 2012, 17, 923-937. [CrossRef] 
11. El Kharraz, J.; El-Sadek, A.; Ghaffour, N.; Mino, E. Water scarcity and drought in WANA countries. Procedia Eng. $2012,33,14-29$. [CrossRef]

12. Liu, M.; Xu, X.; Xu, C.; Sun, A.Y.; Wang, K.; Scanlon, B.R.; Zhang, L. A new drought index that considers the joint effects of climate and land surface change. Water Resour. Res. 2017, 53, 3262-3278. [CrossRef]

13. Deo, R.C.; Syktus, J.I.; McAlpine, C.A.; Lawrence, P.J.; McGowan, H.A.; Phinn, S.R. Impact of historical land cover change on daily indices of climate extremes including droughts in eastern Australia. Geophys. Res. Lett. 2009, 36, L08705. [CrossRef]

14. Lee, J.E.; Lintner, B.R.; Boyce, C.K.; Lawrence, P.J. Land use change exacerbates tropical South American drought by sea surface temperature variability. Geophys. Res. Lett. 2011, 38, L19706. [CrossRef]

15. Wilhite, D.A.; Glantz, M.H. Understanding: The drought phenomenon: The role of definitions. Water Int. 1985, 10, 111-120. [CrossRef]

16. Smakhtin, V.U.; Hughes, D.A. Automated estimation and analyses of meteorological drought characteristics from monthly rainfall data. Environ. Model. Softw. 2007, 22, 880-890. [CrossRef]

17. Tallaksen, L.M.; Van Lanen, H.A.J. (Eds.) Hydrological Drought: Processes and Estimation Methods for Streamflow and Groundwater. In Developments in Water Science; Elsevier Science: Amsterdam, The Netherlands, 2004; Volume 48.

18. Nalbantis, I.; Tsakiris, G. Assessment of hydrological drought revisited. Water Resour. Manag. 2009, 23, 881-897. [CrossRef]

19. Clausen, B.; Pearson, C.P. Regional frequency analysis of annual maximum streamflow drought. J. Hydrol. 1995, 173, 111-130. [CrossRef]

20. Rickard, D.S. The occurrence of agricultural drought at Ashburton, New Zealand. N. Z. J. Agric. Res. 1960, 3, 431-441. [CrossRef]

21. Nieuwolt, S. Agricultural droughts in the tropics. Appl. Clim. 1986, 37, 29-38. [CrossRef]

22. Eklund, L.; Seaquist, J. Meteorological, agricultural and socioeconomic drought in the Duhok Governorate, Iraqi Kurdistan. Nat. Hazards 2015, 76, 421-441. [CrossRef]

23. Mehran, A.; Mazdiyasni, O.; AghaKouchak, A. A hybrid framework for assessing socioeconomic drought: Linking climate variability, local resilience, and demand. J. Geophys. Res. 2015, 120, 7520-7533. [CrossRef]

24. Carrão, H.; Naumann, G.; Barbosa, P. Global projections of drought hazard in a warming climate: A prime for disaster risk management. Clim. Dyn. 2018, 50, 2137-2155. [CrossRef]

25. Ahmadalipour, A.; Moradkhani, H.; Castelletti, A.; Magliocca, N. Future drought risk in Africa: Integrating vulnerability, climate change, and population growth. Sci. Total Environ. 2019, 662, 672-686. [CrossRef] [PubMed]

26. Smith, A.B.; Katz, R.W. US billion-dollar weather and climate disasters: Data sources, trends, accuracy and biases. Nat. Hazards 2013, 67, 387-410. [CrossRef]

27. Smith, A.B.; Matthews, J.L. Quantifying uncertainty and variable sensitivity within the US billion-dollar weather and climate disaster cost estimates. Nat. Hazards 2015, 77, 1829-1851. [CrossRef]

28. Carrão, H.; Naumann, G.; Barbosa, P. Mapping global patterns of drought risk: An empirical framework based on sub-national estimates of hazard, exposure and vulnerability. Glob. Environ. Chang. 2016, 39, 108-124. [CrossRef]

29. Vicente-Serrano, S.M.; Beguería, S.; Gimeno, L.; Eklundh, L.; Giuliani, G.; Weston, D.; El Kenawy, A.; López-Moreno, J.I.; Nieto, R.; Ayenew, T.; et al. Challenges for drought mitigation in Africa: The potential use of geospatial data and drought information systems. Appl. Geogr. 2012, 34, 471-486. [CrossRef]

30. Andreadis, K.M.; Lettenmaier, D.P. Trends in 20th century drought over the continental United States. Geophys. Res. Lett. 2006, 33, L10403. [CrossRef]

31. Grillakis, M.G. Increase in severe and extreme soil moisture droughts for Europe under climate change. Sci. Total Environ. 2019, 660, 1245-1255. [CrossRef] [PubMed]

32. Sparks, R.E. Need for ecosystem management of large rivers and their floodplains-These phenomenally productive ecosystems produce fish and wildlife and preserve species. Bioscience 1995, 45, 168-182. [CrossRef]

33. Bunn, S.E.; Arthington, A.H. Basic principles and ecological consequences of altered flow regimes for aquatic biodiversity. Environ. Manag. 2002, 30, 492-507. [CrossRef] [PubMed]

34. Taylor, C.M.; Millican, D.S.; Roberts, M.E.; Slack, W.T. Long-term change to fish assemblages and the flow regime in a southeastern U.S. river system after extensive aquatic ecosystem fragmentation. Ecography 2008, 31, 787-797. [CrossRef]

35. Poff, N.L.; Allan, J.D.; Bain, M.B.; Karr, J.R.; Prestegaard, K.L.; Richter, B.D.; Sparks, R.E.; Stromberg, J.C. The natural flow regime: A paradigm for river conservation and restoration. Bioscience 1997, 47, 769-784. [CrossRef]

36. Lytle, D.A.; Poff, N.L. Adaptation to natural flow regimes. Trends. Ecol. Evol. 2004, 19, 94-100. [CrossRef]

37. Naiman, R.J.; Latterell, J.J.; Pettit, N.E.; Olden, J.D. Flow variability and the biophysical vitality of river systems. C. R. Geosci. 2008, 340, 629-643. [CrossRef]

38. Kennard, M.J.; Pusey, B.J.; Olden, J.D.; MacKay, S.J.; Stein, J.L.; Marsh, N. Classification of natural flow regimes in Australia to support environmental flow management. Freshw. Biol. 2010, 55, 171-193. [CrossRef]

39. Obled, C.; Wendling, J.; Beven, K. The sensitivity of hydrological models to spatial rainfall patterns: An evaluation using observed data. J. Hydrol. 1994, 159, 305-333. [CrossRef]

40. Montgomery, D.R.; Dietrich, W.E.; Torres, R.; Anderson, S.P.; Heffner, J.T.; Loague, K. Hydrologic response of a steep, unchanneled valley to natural and applied rainfall. Water Resour. Res. 1997, 33, 91-109. [CrossRef]

41. Kashaigili, J.J. Impacts of land-use and land-cover changes on flow regimes of the Usangu wetland and the Great Ruaha River, Tanzania. Phys. Chem. Earth 2008, 33, 640-647. [CrossRef] 
42. McIntyre, N.; Marshall, M. Identification of rural land management signals in runoff response. Hydrol. Process. 2010, 24, 3521-3534. [CrossRef]

43. Meijerink, A.M.J. Estimates of peak runoff from hilly terrain with varied lithology. J. Hydrol. 1985, 77, 227-236. [CrossRef]

44. Mushiake, K.; Takahashi, Y.; Ando, Y. Effects of basin geology on river-flow regime in mountainous areas of Japan. Proc. Jpn. Soc. Civ. Eng. 1981, 309, 51-62. [CrossRef]

45. Zecharias, Y.B.; Brutsaert, W. The influence of basin morphology on groundwater outflow. Water Resour. Res. 1988, 24, 1645-1650. [CrossRef]

46. Vogel, R.M.; Kroll, C.N. Regional geohydrologic-geomorphic relationships for the estimation of low-flow statistics. Water Resour. Res. 1992, 28, 2451-2458. [CrossRef]

47. Laaha, G.; Blöschl, G. Low flow estimates from short stream flow records-A comparison of methods. J. Hydrol. 2005, 306, 264-286. [CrossRef]

48. Laaha, G.; Blöschl, G. A comparison of low flow regionalisation methods-catchment grouping. J. Hydrol. 2006, 323, 193-214. [CrossRef]

49. Japan Dam Foundation. Dam Year Directory; Japan Dam Foundation: Tokyo, Japan, 2019.

50. Itsukushima, R.; Shimatani, Y. Comparative study on flow regime in Kyushu Island. Annu. J. Hydraul. Eng. JSCE 2015, 71, I_1213-I_1218.

51. Itsukushima, R.; Tanaka, W.; Shimatani, Y. Influence of watershed characteristics on flood discharge at 46 water level stations in Japan: Findings from factor analysis at different scale of flood. Annu. J. Hydraul. Eng. JSCE 2016, 72, I_1255-I_1260.

52. Changnon, S.A. Detecting drought conditions in Illinois. Ill. State Water Surv. Champaign Circ. 1987, 169, 1-41.

53. Van Loon, A.F. Hydrological drought explained. Wiley Interdiscip. Rev. Water 2015, 2, 359-392. [CrossRef]

54. Agnew, C.; Warren, A. A framework for tackling drought and land degradation. J. Arid. Environ. 1996, 33, 309-320. [CrossRef]

55. McMahon, T.A.; Finlayson, B.L. Droughts and anti-droughts: The low flow hydrology of Australian rivers. Freshw. Biol. 2003, 48, 1147-1160. [CrossRef]

56. Henny, C.J.; Hill, E.F.; Grove, R.A.; Kaiser, J.L. Mercury and Drought along the Lower Carson River, Nevada: I. Snowy Egret and Black-Crowned Night-Heron Annual Exposure to Mercury, 1997-2006. Arch. Environ. Contam. Toxicol. 2007, 53, 269-280. [CrossRef]

57. Lorenzo-Lacruz, J.; Vicente-Serrano, S.M.; López-Moreno, J.I.; Beguería, S.; García-Ruiz, J.M.; Cuadrat, J.M. The impact of droughts and water management on various hydrological systems in the headwaters of the Tagus River (central Spain). J. Hydrol. 2010, 386, 13-26. [CrossRef]

58. Yue, S.; Ouarda, T.B.M.J.; Bobée, B.; Legendre, P.; Bruneau, P. The Gumbel mixed model for flood frequency analysis. J. Hydrol. 1999, 226, 88-100. [CrossRef]

59. Takara, K.; Tosa, K. Application of probability distributions with lower and upper bounds to hydrologic frequency analysis. Proc. Hydraul. Eng. JSCE 1999, 43, 121-126. [CrossRef]

60. Griffis, V.W.; Stedinger, J.R. Log-Pearson type 3 distribution and Its application in flood frequency analysis. I: Distribution characteristics. J. Hydrol. Eng 2007, 12, 482-491. [CrossRef]

61. Takara, K.; Takasao, T. Comparison of parameter estimation methods for hydrologic frequency analysis model. Proc. Hydraul. Eng. JSCE 1990, 34, 7-12. [CrossRef]

62. Ishihara, T.; Takase, N. The logarithmic-normal distribution and its solution based on moment method. Trans. Jpn. Soc. Civ. Eng. 1957, 47, 18-23. [CrossRef]

63. Griffis, V.W. Flood Frequency Analysis: Bulletin 17, Regional Information, and Climate Change. Ph.D. Dissertation, Cornell University, Ithaca, NY, USA, 2006.

64. Interagency Committee on Water Data. Guidelines for Determining Flood Flow Frequency: Bulletin 17 B (Revised and Corrected); Hydrology Subcommittee: Washington, DC, USA, 1982; pp. 1-28.

65. Takara, K. Frequency analysis of hydrological extreme events and how to consider climate change. In Proceedings of the Nineteenth IHP Training Course (International Hydrological Program), Kyoto, Japan, 29 November-12 December 2009.

66. Etoh, T.; Murota, A.; Nakanishi, M. SQRT-exponential type distribution of maximum. In Hydrologic Frequency Modeling; Springer Science and Business Media LLC: Dordrecht, The Netherlands, 1987; pp. 253-264.

67. Stedinger, J.R.; Vogel, R.M.; Foufoula-Georgiou, E. Chapter 18-Frequency analysis of extreme events. In Handbook of Hydrology; Maidment, D.R., Ed.; McGraw-Hill: New York, NY, USA, 1993.

68. Takasao, T.; Takara, K.; Shimizu, A. A basic study on frequency analysis of hydrological data in the Lake Biwa basin. Disaster Prev. Res. Inst. Annu. Kyoto Univ. 1986, 29, 157-171.

69. Takara, K.; Kobayashi, K. Hydraulic analysis methods suitable to the sample size of extreme events. Annu. J. Hydraul. Eng. JSCE 2009, 53, 205-210.

70. Wilhite, D.A. Drought as a Natural Hazard: Concepts and Definitions; Drought Mitigation Center Faculty Publications: Lincoln, NE, USA, 2000; p. 69.

71. Whipple, W. Regional drought frequency analysis. Proc. ASCE 1966, 92, 11-31.

72. Changnon, S.A. Removing the confusion over droughts and floods: The interface between scientists and policy makers. Water Int. 1980, 5, 10-18. [CrossRef] 
73. Burrough, P.A.; McDonell, R.A. Principles of Geographical Information Systems; Oxford University Press: New York, NY, USA, 1998; p. 190.

74. Horton, R.E. Drainage Basin Characteristic. Trans. Am. Geophys. Union 1932, 13, 350-361. [CrossRef]

75. Miller, V.C. A quantitative geomorphic study of drainage basin characteristics in the Clinch mountain area, Virginia and Tennessee. J. Geol. 1953, 65, 30.

76. Kruskal, J.B. Multidimensional scaling by optimizing goodness of fit to a nonmetric hypothesis. Psychometrika 1964, $29,1-27$. [CrossRef]

77. Coxon, A.P.M. The User's Guide to Multidimensional Scaling; Heinemann: London, UK, 1982.

78. Gauch, H.G. Multivariate Analysis in Community Ecology. Cambridge Studies in Ecology 1; Cambridge University Press: Cambridge, $\mathrm{UK}, 1982$.

79. Whittaker, R.J. An application of detrended correspondence analysis and non- metric multidimensional scaling to the identification and analysis of environmental factor complexes and vegetation structures. J. Ecol. 1987, 75, 363-376. [CrossRef]

80. Bray, J.R.; Curtis, J.T. An Ordination of the Upland Forest Communities of Southern Wisconsin. Ecol. Monogr. 1952, 27, 325-349. [CrossRef]

81. McCullagh, P.; Nelder, J. Generalized Linear Models, 2nd ed.; Chapman and Hall/CRC: Boca Raton, FL, USA, 1989.

82. Burnham, K.P.; Anderson, D.R. Model Selection and Multi-Model Inference, 2nd ed.; Springer: Berlin, Germany, 2002; Volume 26, p. 488.

83. Efroymson, M.A. Multiple regression analysis. In Mathematical Methods for Digital Computers; Ralston, A., Wilf, H.S., Eds.; Wiley: New York, NY, USA, 1960.

84. Ali, G.; Tetzlaff, D.; Soulsby, C.; McDonnell, J.J.; Capell, R. A comparison of similarity indices for catchment classification using a cross-regional dataset. Adv. Water Resour. 2012, 40, 11-22. [CrossRef]

85. Sawicz, K.; Wagener, T.; Sivapalan, M.; Troch, P.A.; Carrillo, G. Catchment classification: Empirical analysis of hydrologic similarity based on catchment function in the eastern USA. Hydrol. Earth Syst. Sci. 2011, 15, 2895-2911. [CrossRef]

86. Wagner, T.; Sivapalan, M.; Troch, P.; Woods, R. Catchment Classification and Hydrologic Similarity. Geogr. Compass 2007, 1, 901-931. [CrossRef]

87. Carey, S.K.; Tetzlaff, D.; Seibert, J.; Soulsby, C.; Buttle, J.; Laudon, H.; McDonnell, J.; McGuire, K.; Caissie, D.; Shanley, J.; et al. Inter-comparison of hydro-climatic regimes across northern catchments: Synchronicity, resistance and resilience. Hydrol. Process. 2010, 24, 3591-3602. [CrossRef]

88. Ahn, C.-H.; Tateishi, R. Development of Global Land Surface Evapotranspiration and Water Balance Data Sets. J. Jpn. Soc. Photogramm. Remote Sens. 1994, 33, 48-61. [CrossRef]

89. Zhang, K.; Kimball, J.S.; Kim, Y.; Mcdonald, K.C. Changing freeze-thaw seasons in northern high latitudes and associated influences on evapotranspiration. Hydrol. Process. 2011, 25, 4142-4151. [CrossRef]

90. Takahashi, Y.; Kurihara, H.; Kinoshira, T.; Ishizaki, K.; Mushiake, K. River Hydrol; Kyoritsu Shuppan: Tokyo, Japan, 1978.

91. Wada, K.; Murase, M.; Tomizawa, Y. Study on the variation of rainfall characteristic and flood and drought risks assessment of global warming. Proc. JSCE II Hydraul. Sanit. Eng. 2005, 796, 23-37.

92. Arao, K.; Kaneko, K. Regional singularities of heavy rain in June and July in Kyushu. Sci. Bull. Fac. Educ. Nagasaki Univ. 1985, 36, $17-24$.

93. Sudo, S. Distribution and proportion of rock and geological layer in Japan. Aggreg. Resour. Investig. Rep. 2006, 56-65.

94. Berger, K.P.; Entekhabi, D. Basin hydrologic response relations to distributed physiographic descriptors and climate. J. Hydrol. 2001, 247, 169-182. [CrossRef]

95. Peters, E.; Torfs, P.J.J.F.; van Lanen, H.A.J.; Bier, G. Propagation of drought through groundwater-A new approach using linear reservoir theory. Hydrol. Process. 2003, 17, 3023-3040. [CrossRef]

96. Peters, E.; Van Lanen, H.A.J.; Torfs, P.J.J.F.; Bier, G. Drought in groundwater-Drought distribution and performance indicators. J. Hydrol. 2005, 306, 302-317. [CrossRef]

97. Salinas, J.L.; Laaha, G.; Rogger, M.; Parajka, J.; Viglione, A.; Sivapalan, M.; Blöschl, G. Comparative assessment of predictions in ungauged basins-Part 2: Flood and low flow studies. Hydrol. Earth Syst. Sci. 2013, 17, 2637-2652. [CrossRef]

98. Lacey, G.C.; Grayson, R.B. Relating baseflow to catchment properties in south-eastern Australia. J. Hydrol. 1998, 204, 231-250. [CrossRef]

99. Bloomfield, J.P.; Allen, D.J.; Griffiths, K.J. Examining geological controls on baseflow index (BFI) using regression analysis: An illustration from the Thames Basin, UK. J. Hydrol. 2009, 373, 164-176. [CrossRef]

100. Yokoo, Y.; Oki, T. Effects of climate, topography, soil, geology and land use on flow regimes in Japanese mountainous watersheds. Annu. J. Hydraul. Eng. JSCE 2010, 54, 469-474.

101. Gaál, L.; Szolgay, J.; Kohnová, S.; Parajka, J.; Merz, R.; Viglione, A.; Blöschl, G. Flood timescales: Understanding the interplay of climate and catchment processes through comparative hydrology. Water Resour. Res. 2012, 48, W04511. [CrossRef]

102. Condon, L.E.; Maxwell, R.M. Evaluating the relationship between topography and groundwater using outputs from a continentalscale integrated hydrology model. Water Resour. Res. 2015, 51, 6602-6621. [CrossRef]

103. Andréassian, V. Waters and forests: From historical controversy to scientific debate. J. Hydrol. 2004, 291, 1-27. [CrossRef]

104. Calder, I.R. Evaporation in the Uplands; Wiley: Chichester, UK, 1990; p. 148. 
105. Zhang, L.; Dawes, W.R.; Walker, G.R. Response of mean annual evapotranspiration to vegetation changes at catchment scale. Water Resour. Res. 2001, 37, 701-708. [CrossRef]

106. Hirano, H.; Terajima, T.; Nakamura, T.; Sakai, M.; Aoki, F.; Nanami, A. The differences in the short-term runoff characteristics between the coniferous catchment and the deciduous catchment: The effects of storm size on stormflow generation processes of small forested catchments. J. Jpn. Soc. Hydrol. Water Resour. 2009, 22, 24-39. [CrossRef]

107. Bosch, J.M.; Hewlett, J.D. A review of catchment experiments to determine the effect of vegetation changes on water yield and evapotranspiration. J. Hydrol. 1982, 55, 3-23. [CrossRef]

108. Brown, A.E.; Zhang, L.; McMahon, T.A.; Western, A.W.; Vertessy, R.A. A review of paired catchment studies for determining changes in water yield resulting from alterations in vegetation. J. Hydrol. 2005, 310, 28-61. [CrossRef]

109. Maita, E.; Suzuki, M. Change in the Monthly Water Yield after Clear-cutting in Fukuroyamasawa, Chiba. J. Jpn. For. Soc. 2007, 89, 278-287. [CrossRef]

110. Maita, E.; Suzuki, M. The effect of forest cutting on flow duration curve of mountainous small watershed: Evaluation of the influence of vegetation on inter-watershed variation in flow duration curve. J. Jpn. For. Soc. 2008, 90, 36-45. [CrossRef]

111. Scott, D.F.; Lesch, W. Streamflow responses to afforestation with Eucalyptus grandis and Pinus patula and to felling in the Mokobulaan experimental catchments, South Africa. J. Hydrol. 1997, 199, 360-377. [CrossRef]

112. Sakai, Y.; Hirano, T.; Aoki, T.; Terajima, T.; Natsuhara, Y. The effects of tree species and forest management on the short-term runoff characteristics of the small catchments. J. Jpn. Soc. Reveg. Technol. 2009, 35, 306-317. [CrossRef]

113. Rasoulzadeh, A.; Homapoor Ghoorabjiri, M. Comparing hydraulic properties of different forest floors. Hydrol. Process. 2014, 28, 5122-5130. [CrossRef]

114. Fohrer, H.; Haverkamp, K.; Eckhardt, K.; Frede, H.G. Hydrologic response to land use changes on the catchment scale. Phys. Chem. Earth Part. B Hydrol. Oceans Atmos. 2001, 26, 577-582. [CrossRef]

115. Brown, L.R.; Cuffney, T.F.; Coles, J.F.; Fitzpatrick, F.; McMahon, G.; Steuer, J.; Bell, A.H.; May, J.T. Urban streams across the USA: Lessons learned from studies in 9 metropolitan areas. J. N. Am. Benthol. Soc. 2009, 28, 1051-1069. [CrossRef]

116. Poff, N.L.; Bledsoe, B.P.; Cuhaciyan, C.O. Hydrologic variation with land use across the contiguous United States: Geomorphic and ecological consequences for stream ecosystems. Geomorphology 2006, 79, 264-285. [CrossRef]

117. Simmons, D.L.; Reynolds, R.J. Effects of Urbanization on Base Flow of Selected South-Shore Streams, Long Island, New York. J. Am. Water Resour. 1982, 18, 797-805. [CrossRef]

118. Leopold, L.B. Hydrology for Urban Planning-A Guidebook on the Hydrologic Effects of Urban Land Use; U.S. Geological Survey Circular 554; U.S. Geological Survey: Washington, DC, USA, 1968.

119. Merz, R.; Blöschl, G. A regional analysis of event runoff coefficients with respect to climate and catchment characteristics in Austria. Water Resour. Res. 2009, 45, W01405. [CrossRef]

120. Moliere, D.R.; Lowry, J.B.C.; Humphrey, C.L. Classifying the flow regime of data-limited streams in the wet-dry tropical region of Australia. J. Hydrol. 2009, 367, 1-13. [CrossRef]

121. Engeland, K.; Hisdal, H. A comparison of low flow estimates in ungauged catchments using regional regression and the HBV-model. Water Resour. Manag. 2009, 23, 2567-2586. [CrossRef]

122. Castellarin, A.; Galeati, G.; Brandimarte, L.; Montanari, A.; Brath, A. Regional flow-duration curves: Reliability for ungauged basins. Adv. Water Resour. 2004, 27, 953-965. [CrossRef]

123. Abebe, A.; Foerch, G. Catchment characteristics as predictors of base flow index (BFI) in Wabishebele river basin, East Africa. In Proceedings of the Conference on International Agricultural Research for Development, Uppsala, Sweden, 22-23 September 2015; pp. 1-8.

124. Horton, R.E. Erosional development of streams and their drainage basins; Hydrophysical approach to quantitative morphology. Bull. Geol. Soc. Am. 1945, 56, 275-370. [CrossRef]

125. Strahler, A.N. Quantitative analysis of watershed geomorphology. Eos Trans. Am. Geophys. Union 1957, 38, 913-920. [CrossRef]

126. Berne, A.; Uijlenhoet, R.; Troch, P.A. Similarity analysis of subsurface flow response of hillslopes with complex geometry. Water Resour. Res. 2005, 41,1-10. [CrossRef] 